\title{
Optimization of visibility and quantification of aberrant crypt foci in colonic mucosa in Wistar rats ${ }^{1}$
}

\author{
Otimização da visibilidade e quantificação de focos de criptas aberrantes em mucosa cólica de \\ ratos Wistar
}

\author{
${ }^{\text {I}}$ Fellow PhD degree, Postgraduate Program in Surgery, UFC, Ceará, Brazil.

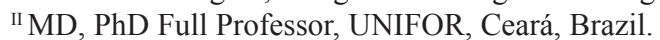

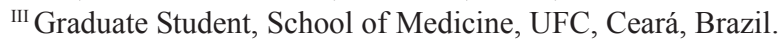 \\ ${ }^{\text {IV }}$ Graduate Student, School of Medicine, FMJ, Brazil. \\ ${ }^{v} \mathrm{PhD}$, Associate Professor, Department of Surgery, UFC, Ceará, Brazil.
}

Idália Maria Brasil Burlamaqui ${ }^{I}$, Conceição Aparecida Dornelas ${ }^{I}$, Rodrigo Dornenfeld Escalante ${ }^{\text {II }}$, Daniel Magalhães Coutinho

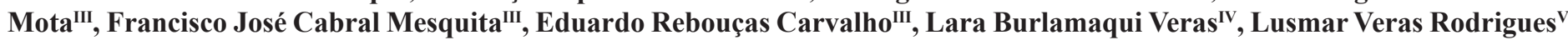

\begin{abstract}
Purpose: Test immersion of microscopy samples in water as an aid to visualizing and quantifying aberrant crypt foci (ACF) in rat colon mucosa. Methods: Carcinogenesis was induced with azoxymethane in Wistar rats kept on a conventional diet or a hypercaloric diet containing unsaturated fat. Fifteen weeks after induction, colon samples were retrieved and fixated in a $10 \%$ formaldehyde solution. The samples were divided into segments (distal, middle, proximal) and stained with $1 \%$ toluidine blue. The technique tested in the study consisted of immersing microscopy samples in distilled water in order to eliminate the problem of light reflection known from conventional microscopy. Results: When samples were immersed in water during microscopy, significantly more ACF could be visualized in all colon segments than with the conventional method proposed by Bird. Conclusion: Immersing microscopy samples in water aids the visualization and quantification of aberrant crypt foci in rat colon mucosa fixed in formaldehyde.
\end{abstract}

Key words: Precancerous Conditions. Colorectal Neoplasms. Azoxymethane. Rats.

\section{RESUMO}

Objetivo: Otimizar a visibilização de focos de criptas aberrantes (FCA) em mucosa cólica de ratos Wistar. Métodos: Colo de rato Wistar, sob diferentes dietas e submetidos a iniciação de carcinogênese pelo azoximetano há 4 meses, foram previamente lavados, abertos e fixados em solução de formalina a $10 \%$ por 24 horas. Após serem corados em azul de toluidina a 1\%, foram divididos em segmentos distal, médio e proximal e imersos em água destilada para quantificação de FCA. Resultados: No método de imersão foi visibilizado maior quantidade de focos de criptas aberrantes em todos os segmentos cólicos, com diferença significante, quando comparado com o método de Bird. Conclusão: O método de imersão otimiza a visibilização e quantificação de focos de criptas aberrantes em mucosa cólica (ratos Wistar) fixada em solução de formalina a $10 \%$.

Descritores: Lesões Pré-Cancerosas. Neoplasias Colorretais. Azoximetano. Ratos.

${ }^{1}$ Research performed at Postgraduate Program in Surgery, Medical School, Federal University of Ceará (UFC), Brazil.

\section{Introduction}

Colon carcinogenesis has been investigated widely by administrating carcinogenic substances to experimental animals ${ }^{1}$. The emergence of aberrant crypt foci (ACF) is one of the most important outcome parameters in such models ${ }^{2}$.

ACF in colonic mucosa stained with toluidine blue is usually darker and larger than normal crypt foci and tend to occur in isolation, in pairs or in small clusters. Foci may be rounded, fusiform or concave ${ }^{2}$.

Bird in 1987 proposed a method for visualizing ACF in samples of rat colon using light microscopy at 40X. Many researchers have since then employed the method in study protocols, clinical practice and colonoscopic screening for pre-neoplastic lesions ${ }^{3-6}$.

The objective of this study was to test immersion of microscopy samples in water as an aid to visualizing and quantifying aberrant crypt foci (ACF) in rat colon mucosa.

\section{Methods}

The study was previously approved by the Ethics Committee for Animal Research of the Federal University of Ceara (CEPA/UFC: protocol \#11/06). The use of laboratory animals followed the Council for International Organization of Medical Sciences ethical code for animals experimentation and the Brazilian College on Animal Experimentation. 
The experimental population consisted of 18 eight-week old Wistar rats weighing $250 \mathrm{~g}$ on the average. The animals were randomly distributed, housed in polypropylene cages lined with wood shavings and kept in a 12/12-hour circadian rhythm at room temperature $\left(22^{\circ} \mathrm{C}\right)$ and continuous air circulation.

The animals were fed ad libitum. Eight weeks into the study period, carcinogenesis was induced with $15 \mathrm{mg} / \mathrm{kg}$ azoxymethane administered peritoneally once a week for two weeks.

Fifteen weeks after the first dose of azoxymethane, the animals were euthanized with $80 \mathrm{mg} / \mathrm{kg}$ ketamine and $8 \mathrm{mg} / \mathrm{kg}$ xylazine. The colon was carefully resected and $1 \mathrm{~cm}$ of tissue proximal to the anal border was discarded. Subsequently, the colon was catheterized at the proximal extremity, rinsed with physiological

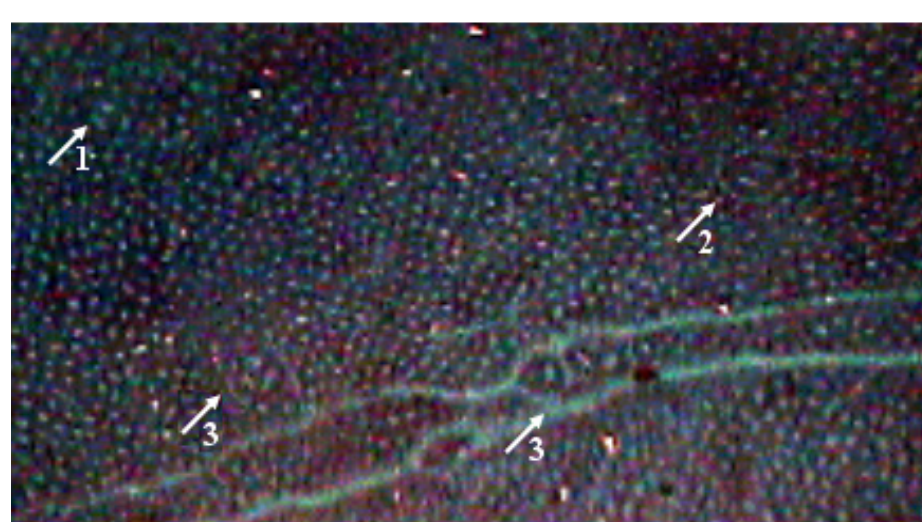

FIGURE 1 - Aberrant crypt foci in colonic mucosa of Wistar rats. Arrows show FCA with 3, 2 and 1 aberrant crypt

The findings were analyzed by pooling the data from the two groups into a single group of 18 animals. The total number of ACF observed in the colonic mucosa was compared for the different segments (distal, middle and proximal) and methods. The statistical significance of the differences observed between segments and methods was verified with the Kolmogorov-Smirnov test and Wilcoxon's and Student's paired $t$ tests. saline, opened along the antimesenteric border, laid out on kraft paper and rolled up, then fixated in 10\% formaldehyde for 24 hours. After fixation, each colon was divided into three segments of equal length (distal, middle and proximal). The labeled segments were stained in $1 \%$ toluidine blue for 1 minute.

The ACF (Figure 1) were quantified for all segments by the same researcher using the Bird's method (conventional) or the method with immersion of sample in water. In the conventional method, the stained segments were mounted individually on glass slides; in the second method, the stained segments were immersed in $20 \mathrm{ml}$ distilled water on Petri dish glass bottom plan, simple wall with $1.2 \mathrm{~mm}$ thick, Format $90 \times 15 \mathrm{~mm}$ (Figure 2). All samples were examined with a stereoscopic light microscope (DF Vasconcellos M90, Vasconcellos S.A.) at 40X magnification.

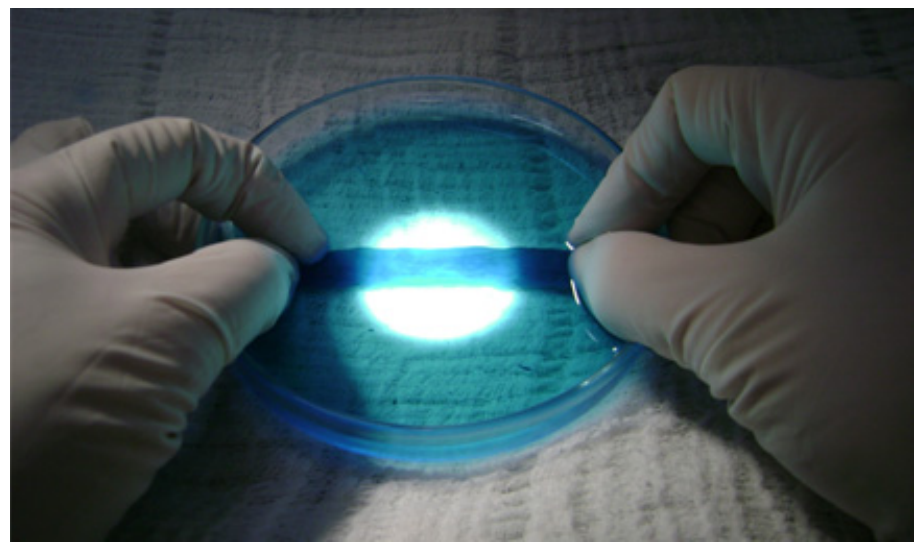

FIGURE 2 - Immersion of colon segment in distilled water

\section{Results}

The data for the distal and middle segments were normally distributed according to the Kolmogorov-Smirnov test and were analyzed with Student's paired $t$ test. The data for the proximal segments did not present normal distribution and were analyzed with Wilcoxon's paired $t$ test. The total numbers of ACF for each type of segment and method are listed in Table 1.

TABLE 1 - Total number of colonic mucosal aberrant crypt foci (ACF) in colon samples from 18 Wistar rats according to colon segment and visualization method

\begin{tabular}{lccccc}
\hline $\begin{array}{c}\text { ACF } \\
\text { visualization } \\
\text { method }\end{array}$ & $\begin{array}{c}\text { Number } \\
\text { of } \\
\text { animals }\end{array}$ & $\begin{array}{c}\text { Colon } \\
\text { segment }\end{array}$ & $\begin{array}{c}\text { Average } \\
\text { number } \\
\text { of ACF }\end{array}$ & Range & $\begin{array}{c}\text { Standard } \\
\text { deviation }\end{array}$ \\
\hline Conventional & 18 & distal & 37.83 & $13-71$ & 17.365 \\
Immersion & 18 & distal & 52.94 & $16-125$ & 33.618 \\
Conventional & 18 & middle & 52.61 & $16-98$ & 24.032 \\
Immersion & 18 & middle & 69.22 & $20-141$ & 34.550 \\
Conventional & 18 & proximal & 1.28 & $0-8$ & 2.124 \\
Immersion & 18 & proximal & 2.33 & $0-9$ & 2.301 \\
\hline
\end{tabular}


Statisically significant differences were found between the two visualization methods with regard to the number of ACF in all colon segments (Figure 3).

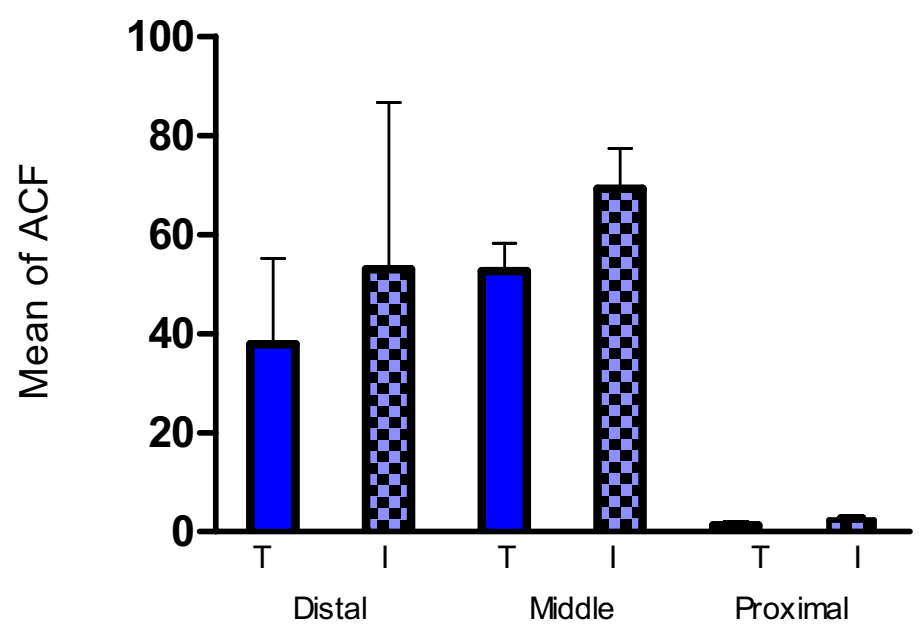

FIGURE 3 - Average number of aberrant crypt foci in the distal $(p=0.045)$, middle $(p=0.011)$ and proximal $(p=0.022)$ segments of rat colon according to visualization method
The total number of ACF for the entire colon by visualization method is shown in Table 2 and in Figure 4.

TABLE 2 - Total number of aberrant crypt foci (ACF) in colons of 18 Wistar rats according to visualization method

\begin{tabular}{lcccc}
\hline $\begin{array}{c}\text { ACF } \\
\text { visualization } \\
\text { method }\end{array}$ & $\begin{array}{c}\text { Number of } \\
\text { animals }\end{array}$ & $\begin{array}{c}\text { Average } \\
\text { number of } \\
\text { ACF }\end{array}$ & Range & $\begin{array}{c}\text { Standard } \\
\text { deviation }\end{array}$ \\
\hline Conventional & 18 & 91.72 & $37-167$ & 34.952 \\
Immersion & 18 & 124.50 & $49-268$ & 61.220 \\
\hline$p=0.013$ & & & &
\end{tabular}

The two visualization methods yielded significantly different results with regard to the multiplicity of ACF in all colon segments when considering foci with up to 4 crypts (Table 3 ).

TABLE 3 - Multiplicity of aberrant crypt foci (ACF) in colons of 18 Wistar rats according to visualization method

\begin{tabular}{lcclccc}
\hline $\begin{array}{c}\text { ACF } \\
\text { visualization } \\
\text { method }\end{array}$ & $\begin{array}{c}\text { Number of } \\
\text { animals }\end{array}$ & $\begin{array}{c}\text { Number of } \\
\text { crypts per } \\
\text { focus }\end{array}$ & $\begin{array}{c}\text { Colon } \\
\text { segment }\end{array}$ & $\begin{array}{c}\text { Average } \\
\text { number of } \\
\text { ACF }\end{array}$ & Range & $\begin{array}{c}\text { Standard } \\
\text { deviation }\end{array}$ \\
\hline Conventional & 18 & $\leq 4$ & distal & 36.28 & $13-66$ & 16.782 \\
Immersion & 18 & $\leq 4$ & distal* & 53.17 & $15-120$ & 31.345 \\
Conventional & 18 & $\leq 4$ & middle & 49.06 & $14-93$ & 22.982 \\
Immersion & 18 & $\leq 4$ & middle** & 64.22 & $17-136$ & 32.363 \\
Conventional & 18 & $\leq 4$ & proximal & 1.28 & $0-8$ & 2.164 \\
Immersion & 18 & $\leq 4$ & proximal*** & 2.22 & $0-8$ & 2.102 \\
\hline
\end{tabular}

$* p=0.028 ; * * p=0.014 ; * * * p=0.034$ 


\section{Discussion}

Several studies has published that aberrant crypt foci in the colonic mucosa is an important biomarker of the morphological changes associated with early-stage colorectal cancer $^{1,7}$.

Bird's method for visualizing ACF in samples of rat colon has been very useful so far, but the method may be improved.

Our findings reveal a statistically significant difference in ACF visualization performance between the conventional method and the immersion method. Thus, more ACF were observed in all colon segments when samples were immersed in water. In addition, ACF quantification required less time with the immersion method due to the elimination of light reflection from the colonic mucosa.

Very few ACF were observed in proximal colon segments with either method. This matches findings from other studies on azoxymethane-induced carcinogenesis in rat colon ${ }^{8}$.

The multiplicity of crypts per focus was compared for the two visualization methods. Significant differences were observed for foci with up to 4 crypts, but not for foci with 5 or more crypts. This may be explained by the fact that foci with fewer crypts are smaller and therefore tend to be difficult to visualize.

In spite of technological advances, aberrant crypts may not be easy to visualize with currently available stereoscopic light microscopes, especially due to the reflection of light from the colonic mucosa. However, as shown in our study, the problem of light reflection may be almost completely eliminated by immersing samples in water.

The professor Jan Erik Paulsen from the Department of Environmental Medicine, National Institute of Public Health, and Department of Pathology, National Hospital (Oslo, Norway), who is known for his research on aberrant crypt, described a visualization technique based on translumination which had not been described in detail in his earlier papers, although the technique has been in use for over nine years ${ }^{10-14}$. With this technique, a few milliliters of formalin solution (similar to the fixation solution) are added to a large plastic Petri dish. The luminal surface of the colon preparation is then turned downwards so the lens under the Petri dish is pointed towards the surface (in an inverse microscope the lens is beneath the preparation while the light above the Petri dish shines through the preparation). Sometimes a glass slide is used to flatten the sample on the Petri dish. The sample should float in formalin.

Paulsen's method differs from the method used in this study in that the colon segment is immersed in formalin and flattened with a slide. It would appear that if the sample is previously fixated in $10 \%$ formaldehyde for 24 hours and returned to the formalin solution immediately after visualization, provided visualization time is short, the specimen will be in a good enough condition be used for other experiments, including staining with hematoxyllineosin and immunohistochemical tests.

Optical physics shows that light passes from one medium to another at an angle corresponding to the difference in the light speed propagation rate of the two media. This change in direction is termed refraction. The index of refraction is calculated by dividing the speed of light in a vacuum by the speed of light in the desired medium ${ }^{9}$.
The index of refraction of air is approximately 1.0, while that of water is nearly 1.33. In the conventional visualization method the perpendicular ray of light emitted by the microscope is reflected by the colonic mucosa, but if the sample is immersed in distilled water, as proposed in the present study, any light reflection is conveniently refracted away from the eye of the observer.

\section{Conclusion}

Immersing microscopy samples in distilled water facilitates the visualization and quantification of aberrant crypt foci in rat colon mucosa fixed in formaldehyde solution.

\section{References}

1. Bird RP. Observation and quantification of aberrant crypts in the murine colon treated with a colon carcinogen: preliminary findings. Cancer Lett. 1987;37:147-51.

2. Fenoglio-Preiser CM, Noffsinger A. Aberrant crypt foci: a review. Toxicol Pathol. 1999;27:632-42.

3. Pretlow TP, Barrow BJ, Ashton WS, O'riordan MA, Pretlow TG, Jurcisek JA, Stellato TA. Aberrant crypts: putative preneoplastic foci in human colonic mucosa. Cancer Res. 1991;51:1564-7.

4. Roncucci L, Stamp D, Medline A, Cullen JB, Bruce WR. Identification and quantification of aberrant crypt foci and microadenomas in the human colon. Hum Pathol. 1991;22:287-94.

5. Takayama T, Katsuki S, Takahashi Y, Ohi M, Nojiri S, Sakamaki S, Kato J, Kogawa, K, Miyake H, Niitsu Y. Aberrant crypt foci of the colon as precursors of adenoma and cancer. N Engl J Med. 1998;339:1277-84. 6. Greenspan EJ, Jablonski MA, Rajan TV, Levine J, Belinsky GS, Rosemberg DW. Epigenetic alterations in RASSF1A in human aberrant crypt foci. Carcinogenesis. 2006;27(7):1316-22.

7. Bazo AP, Rodrigues MA, Sforcin JM, de Camargo JL, Ribeiro LR, Salvadori DM. Protective action of propolis on the rat colon carcinogenesis. Teratog Carcinog Mutagen. 2002;22(3):183-94.

8. Montenegro MA, Sanchez-Negrette M, Lértora WJ, Catuogno MS. Dysplastic crypt foci in molybdenum and tungsten-treated large rat bowel induced with 1,2-dimethylhydrazine. Rev Vet. 2003;14:14-9.

9. Alvarenga B, Máximo A. Física. São Paulo: Scipione; 1997.

10. Paulsen JE, Steffensen I-L, Namork E, Alexander J. Scanning electron microscopy of aberrant crypt foci in rat colon. Carcinogenesis. 1994;15:2371-3

11. Paulsen JE, Namork E, Steffensen I-L, Eide TJ, Alexander J. Identification and quantification of aberrant crypt foci in the colon of Min mice: a murine model of familial adenomatous polyposis. Scand J Gastroenterol. 2000;35:534-9.

12. Paulsen JE, Steffensen I-L, Løberg EM, Husøy T, Namork E, Alexander J. Qualitative and quantitative relationship between dysplastic aberrant crypt foci and tumorigenesis in the Min/1 mouse colon. Cancer Res. 2001;61:5010-5.

13. Paulsen JE, Lberg EM, Ølstørn HB, Knutsen HK, Steffensen IL, Alexander J. Flat dysplastic aberrant crypt foci are related to tumorigenesis in the colon of azoxymethane-treated rats. Cancer Res. 2005;65:121-9.

14. Paulsen JE, Knutsen HK, Ølstørn HB, Løberg EM, Alexander J. Identification of flat dysplastic aberrant crypt foci in the colon of azoxymethane-treated A/J mice. Int J Cancer. 2006;118:540-6. 


\section{Acknowledgements}

This study was supported by the following Brazilian agencies: the National Council for Scientific and Technological Development (CNPq); Surgery Post-graduation Program of Federal University of Ceara; and the Experimental Surgery Laboratory (LABCEX), Federal University of Ceara, Medical School.

Conflict of interest: none

Financial source: $\mathrm{CNPq}$

\section{Correspondence:}

Idália Maria Brasil Burlamaqui

Av. Beira Mar, 3680/2001

60165-121 Fortaleza-CE Brazil

Phone: (55 85)3267-5780

idaliaburlamaqui87@hotmail.com

Received: September 10, 2009

Review: November 11, 2009

Accepted: December 15, 2009

\section{How to cite this article}

Burlamaqui IMB, Dornelas CA, Escalante RD, Mota DMC, Mesquita FJC, Carvalho ER, Veras LB, Rodrigues LV. Optimization of visibility and quantification of aberrant crypt foci in colonic mucosa in Wistar rats. Acta Cir Bras. [serial on the Internet] 2010 Mar-Apr;25(2). Available from URL: http://www.scielo.br/acb 